\title{
Trellis systems, rootstocks and season influence on the phenolic composition of 'Chenin
}

\author{
Blanc' grape
}

\author{
Rayssa Ribeiro da Costa ${ }^{1}$, Antônio Augusto Marques Rodrigues ${ }^{1}{ }^{(0}$, Victor Alexandre Freire de Vasconcelos ${ }^{2}$, João Paulo Dias \\ Costa $^{2}$, Maria Auxiliadora Coêlho de Lima ${ }^{3 *}$ (1)
}

Universidade Federal da Paraíba/Centro de Ciências Agrárias - Depto. de Agronomia, C.P. 66 - 58397-000 Areia, PB - Brasil.

2Universidade Federal do Vale do São Francisco/Centro de Ciências Agrárias, Rod. BR 407, km 119 - 56300-990 Petrolina, PE - Brasil.

3Embrapa Semiárido, Rod. BR-428, km 152 - 56302-970 Petrolina, PE - Brasil.

*Corresponding author <auxiliadora.lima@embrapa.br>

Edited by: Paulo Cesar Sentelhas

Received June 20, 2018

Accepted October 24, 2018
ABSTRACT: The biosynthesis of phenolic compounds might be influenced by environmental factors, such as solar radiation, temperature and relative air humidity, and production system. Some components of the production system, particularly the trellis system and rootstock, might change the phenolic composition of grapes due to microclimate of the cultivation region. In this study, the phenolic profile of 'Chenin Blanc' grapes was characterized with different trellis systems and rootstocks in two consecutive production cycles by using high-performance liquid chromatography under tropical semi-arid conditions. In the second production cycle (JanMay/2016), accumulation of (-) - epicatechin gallate and (-) - epigallocatechin gallate was higher when vigorous rootstocks were trellised to the lyre system, whereas the lyre system associated to rootstock 'SO4' resulted in higher rutin accumulation in the same cycle. There was little influence of the factors studied on trans-resveratrol and piceatannol accumulation. However, a higher accumulation of piceatannol was observed in the second productive cycle compared to cis-resveratrol and trans-resveratrol. This study highlights that accumulation of phenolic compounds is influenced not only by environmental factors typical of the production year season, but also by the trellis system and rootstock adopted. The identification of phenolic compounds in the accumulation stimulated by the combination of trellis system, rootstock, and production season allows to differentiate grape quality and add value to products derived from such combination in a tropical semi-arid region.

Keywords: Vitis vinifera L., phenolic acids, flavonoids, stilbenes, tropical vitiviniculture

\section{Introduction}

In tropical regions, such as the Brazilian Semiarid, high mean annual temperatures and intense solar radiation, along with water availability for irrigation, allow two grape harvests in the year, which change berry composition, quality, and typicity (Protas and Camargo, 2011). However, high temperatures are known to cause oxidative stress both in plant and fruit, leading to protein degradation, membrane lipid peroxidation, and DNA damage (Khaliq et al., 2016). In order to fight oxidative stress, secondary metabolites are activated as defense mechanisms, synthesizing antioxidant enzymes and accumulating phenolic compounds (Wang et al., 2017).

The grape is known to have high contents of phenolic compounds and antioxidants. In tropical conditions, Padilha et al. (2016) and Lima et al. (2014) reported high content of bioactive phenolic compounds and high antioxidant activity in wines and juices, respectively, produced in the Brazilian semi-arid.

Phenolic compounds in berries change the sensory properties of products (juice and wine), particularly stability, color, structure, and astringency (García-Estévez et al., 2017), and increase the antioxidant potential of grape berries, contributing to control or prevention of factors related to metabolic syndromes and several chronic diseases caused by human aging (Antoniolli et al., 2015; Fagherazzi et al., 2014).
Grapevine is a plant with a climbing growth habit; therefore, the vineyard needs a trellis system to provide support for canopy management and for a better exposure of leaves to sunlight (Ferrer et al., 2015). The choice of rootstock must also be considered before planting, as it influences physiological responses and scion development. A compatible rootstock provides better balance between vegetative growth, production, and fruit quality (Miele and Rizzon, 2017). Environmental factors associated to the micro-climate of vineyards influence biosynthesis of bioactive compounds, such as phenolics. Therefore, cultivation and management conditions should be handled in order to increase berry phenolic composition (Downey et al., 2004). Additionally, information on these conditions reveals opportunities to obtain new products from the entire or part of the berry. The aim of this study was to characterize the phenolic profile of 'Chenin Blanc' grapes with different trellis systems and rootstocks in two consecutive production cycles under tropical semi-arid conditions.

\section{Materials and Methods}

\section{Plant material and treatments}

'Chenin Blanc' grapes were harvested from vineyards in an experimental area in Petrolina, Pernambuco $\left(09^{\circ} 09^{\prime} \mathrm{S}, 40^{\circ} 22^{\prime} \mathrm{W}\right.$, altitude $\left.376 \mathrm{~m}\right)$. The climate in the region is BSh type according to Köppen classification, corresponding to a very hot semi-arid region (Alvares 
et al., 2014). Plants were installed on: a) two trellis systems - vertical shoot positioning (VSP, spaced $3.0 \times 1.0$ $\mathrm{m})$ and lyre (spaced $4.2 \times 1.0 \mathrm{~m}$ ); and b) five rootstocks - 'IAC 313', 'IAC 572', 'IAC 766', 'SO4', and 'Paulsen $1103^{\prime}$, choosen among the most adopted in the Brazilian wine-growing sector. The first three roostocks of high vigor and the last two of less vigor. Two production cycles were evaluated in the same area: cycle 1 - from July 01,2015 (pruning) to Oct 29, 2015 (harvest); and cycle 2 - from Jan 27, 2016 (pruning) to May 24, 2016 (harvest). Table 1 shows the climatic data during the period.

The experiment design was a randomized block with plots sub-subdivided over time. The plots were represented by production cycle, subplots corresponded to trellis systems, and sub-subplots corresponded to rootstocks. Three replicates were used, each comprised of ten plants, and plants at both block ends represented the borders. During harvest, nine bunches were sampled from eight plants that represented the useful area of each plot and were taken to the laboratory.

\section{Characterization of phenolic profile}

The phenolic profile of grapes was determined in a sample with 50 berries collected from bunches. The seeds of the berries were removed and their skins and pulps were lyophilized. A solution of $50 \%$ methyl alcohol (first extracting solution) was added to the lyophilized material, which was crushed in liquid nitrogen, homogenized and laid to rest for $1 \mathrm{~h}$. After that, the mixture was centrifuged at $15,000 \times \mathrm{g}$ for $20 \mathrm{~min}$ and the

Table 1 - Monthly meteorological data in the Experimental Field of Bebedouro/Embrapa Semiárido, during production cycles from July to Oct, 2015, and from Jan to May, 2016, where phenolic composition of 'Chenin Blanc' grapes were studied using different trellis systems and rootstocks.

\begin{tabular}{|c|c|c|c|c|c|c|c|c|}
\hline \multirow{2}{*}{ Month } & \multicolumn{3}{|c|}{$\mathrm{T}\left({ }^{\circ} \mathrm{C}\right)$} & \multirow{2}{*}{$\mathrm{RH}$} & \multirow{2}{*}{ Rad. } & \multirow{2}{*}{ Ws. } & \multirow{2}{*}{ Rainfall } & \multirow{2}{*}{ ETO } \\
\hline & Mean & Max. & Min. & & & & & \\
\hline & & & & $\%$ & 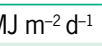 & $\mathrm{m} \mathrm{s}^{-1}$ & $\mathrm{~mm}^{*}$ & $\mathrm{~mm} \mathrm{~d}^{-1}$ \\
\hline \multicolumn{9}{|c|}{ July to Oct, 2015 (Production Cycle 1) } \\
\hline July/15 & 23.7 & 29.4 & 18.7 & 60.9 & 13.0 & 2.9 & 11.9 & 4.4 \\
\hline Aug/15 & 24.8 & 31.2 & 19.0 & 53.6 & 16.2 & 3.0 & 0.5 & 5.4 \\
\hline Sept/15 & 27.4 & 34.3 & 20.9 & 46.5 & 18.6 & 2.7 & 0.3 & 6.3 \\
\hline Oct/15 & 28.3 & 35.3 & 22.2 & 47.0 & 17.8 & 2.8 & 1.5 & 6.4 \\
\hline Mean & 26.0 & 32.6 & 20.2 & 52.0 & 16.4 & 2.9 & 3.6 & 5.6 \\
\hline \multicolumn{9}{|c|}{ Jan to May, 2016 (Production Cycle 2) } \\
\hline Jan/16 & 26.6 & 33.0 & 21.3 & 72.6 & 13.8 & 1.3 & 153.7 & 4.3 \\
\hline Feb/16 & 25.0 & 31.1 & 19.4 & 67.6 & 16.8 & 1.6 & 49.5 & 4.3 \\
\hline Mar/16 & 28.4 & 34.9 & 22.7 & 55.3 & 16.5 & 1.9 & 13.5 & 5.1 \\
\hline Apr/16 & 28.0 & 34.5 & 22.3 & 54.6 & 15.3 & 2.1 & 0.5 & 4.9 \\
\hline May/16 & 26.7 & 33.1 & 20.8 & 57.4 & 13.9 & 2.1 & 5.84 & 4.4 \\
\hline Mean & 26.9 & 33.3 & 21.3 & 61.5 & 15.3 & 1.8 & 44.6 & 4.6 \\
\hline \multicolumn{9}{|c|}{$\begin{array}{l}\text { Mean T. = Mean temperature; T. Max. = Maximum temperature; T. Min. } \\
=\text { Minimum temperature; RH = Relative humidity; Rad. = Global solar } \\
\text { radiation; Ws. = Wind speed at a } 2.0 \mathrm{~m} \text { height; Rainfall = Accumulated } \\
\text { rainfall; ETO = Reference evapotranspiration. }{ }^{*} \text { Total monthly rainfall. Source: } \\
\text { Agrometeorological Station of Bebedouro, Petrolina, Pernambuco - Embrapa } \\
\text { Semiárido (2016). }\end{array}$} \\
\hline
\end{tabular}

supernatant was transferred to a volumetric flask. We added $70 \%$ of acetone (second extracting solution) to the precipitate, which was laid to rest for another $1 \mathrm{~h}$. The mixture was centrifuged at $15,000 \times \mathrm{g}$ for $20 \mathrm{~min}$. The second supernatant was mixed to the first one to obtain the extract (Larrauri et al., 1997).

The extract was filtered using a $0.45 \mu \mathrm{m}$ nylon filter. The volume was transferred to Eppendorf tubes and concentrated in a concentrator for $3 \mathrm{~h}$. Immediately after, the concentrated extract was resuspended in $1 \%$ phosphoric acid in amber vials for a direct reading using high-performance liquid chromatograph (HPLC).

For characterization of the phenolic profile, a Waters 2998 diode array detector (DAD) was used as well as a Waters 2475 fluorescence detector (FLD). Data acquisition and processing were performed using the Waters Empower $^{\mathrm{TM}}$ software. We analyzed 22 commercial standards: gallic acid, caffeic acid, caftaric acid, chlorogenic acid, $p$-coumaric acid, ferullic acid (Sigma-Aldrich); (-) - epicatechin gallate, $(-)$ - epigallocatechin gallate, $(+)$ - catechin, (-) - epicatechin, procyanidin A2, procyanidin B1, procyanidin $\mathrm{B} 2$, kaempferol-3-O-glucoside, isoquercetin, isorhamnetin-3-O-glucoside, myricetin, rutin, cis-resveratrol, trans-resveratrol (Extrasynthese); piceatannol, and viniferin (Sigma-Aldrich). Stock solutions of each standard were prepared in methanol. A pool intermediate solution with the phenolics was prepared by diluting the respective stock solutions in a solution of $1 \%$ phosphoric acid.

Compounds were separated in a Gemini NX C-18 (150 $\mathrm{mm} \times 4.6 \mathrm{~mm} \times 3 \mu \mathrm{m})$ column, in which the mobile phase consisted of a gradient with a mixture between solvent A (solution of $1 \%$ phosphoric acid) and solvent B (acetonitrile) with flow rate of $0.5 \mathrm{~mL} \mathrm{~min}^{-1}$. The initial gradient of $100 \%$ of solvent A was adjusted to $93 \%$ of solvent $\mathrm{A}$ and $7 \%$ of solvent $\mathrm{B}$ in $20 \mathrm{~min}$; $90 \%$ of solvent $\mathrm{A}$ and $10 \%$ of solvent $\mathrm{B}$ in $20 \mathrm{~min} ; 88$ $\%$ of solvent $\mathrm{A}$ and $12 \%$ of solvent $\mathrm{B}$ in $30 \mathrm{~min} ; 77 \%$ of solvent $A$ and $23 \%$ of solvent $B$ in $45 \mathrm{~min} ; 65 \%$ of solvent $A$ and $35 \%$ of solvent B in $45 \mathrm{~min}$; and $100 \%$ of solvent B in 55 min (Natividade et al., 2013). The procedure added extraction and quantification of caftaric acid, cis-resveratrol, viniferin and piceatannol to the method validated by the authors. The main results of validation parameters are shown in Table 2.

For characterization, HPLC was coupled to the DAD and FLD detectors. Wavelengths of $280 \mathrm{~nm}$ [gallic acid, cis-resveratrol, (-) - epicatechin gallate and (-) - epigallocatechin gallate], $320 \mathrm{~nm}$ [caffeic acid, caftaric acid, chlorogenic acid, $p$-coumaric acid, ferullic acid, trans-resveratrol, piceatannol and viniferin], and $360 \mathrm{~nm}$ [kaempferol-3-O-glucoside, isoquercetin, isorhamnetin3-O-glucoside, myricetin and rutin] were used for DAD. For detection in FLD $[(+)$ - catechin, $(-)$ - epicatechin, procyanidin A2, procyanidin B1 and procyanidin B2], excitation occurred at $280 \mathrm{~nm}$ and emission occurred at $320 \mathrm{~nm}$. The two detectors were used simultaneously. Oven temperature was $40{ }^{\circ} \mathrm{C}$, injection volume was 40 $\mu \mathrm{L}$ and running time $60 \mathrm{~min}$. 
Table 2 - Parameters of method validation for quantification of phenolic compounds caftaric acid (CA), cis-resveratrol (CR), viniferin (VN) and piceatannol (PT).

\begin{tabular}{lcccc}
\hline & \multicolumn{1}{c}{$\mathrm{CA}$} & $\mathrm{CR}$ & $\mathrm{VN}$ & $\mathrm{PT}$ \\
\hline Detection limit $\left(\mu \mathrm{g} \mathrm{L}^{-1}\right)$ & 0.164 & 0.024 & 0.004 & 0.176 \\
Quantification limit $\left(\mu \mathrm{g} \mathrm{L}^{-1}\right)$ & 0.548 & 0.084 & 0.013 & 0.587 \\
Linearity assessment $\left(\mu \mathrm{g} \mathrm{L}^{-1}\right)$ & $0.625-80$ & $0.3125-40$ & $0.3125-40$ & $0.3125-40$ \\
Equation & $\mathrm{Y}=3.11 \mathrm{e}+004 \mathrm{X}-1.43 \mathrm{e}$ & $\mathrm{Y}=5.70 \mathrm{e}+004 \mathrm{X}-1.42 \mathrm{e}$ & $\mathrm{Y}=5.57 \mathrm{e}+004 \mathrm{X}-3.97 \mathrm{e}$ & $\mathrm{Y}=1.29 \mathrm{e}+005 \mathrm{X}-6.48 \mathrm{e}$ \\
$\mathrm{R}^{2}$ & +004 & +004 & +004 & +004 \\
Recovery percentage & 0.997307 & 0.999634 & 0.998719 & 0.999282 \\
CVR & $96.93(88.92-104.94)$ & $104.54(92.70-116.39)$ & $88.09(82.27-93.91)$ & $109.93(107.46-112.42)$ \\
Precision (CV\%) & $0.24-0.56$ & $0.73-2.00$ & $1.00-3.22$ & $0.71-3.21$ \\
\hline
\end{tabular}

$\mathrm{R}^{2}=$ coefficient of determination; $\mathrm{CVR}=$ coefficient of variation under repeatability conditions.

\section{Data analysis}

The data was evaluated for normal distribution using the Shapiro-Wilk test. The data with normality assumption were submitted to an analysis of variance using the $\mathrm{F}$ test, comparing the mean values of isolated effects of plots, subplots, and sub-subplots, as well as possible interactions between them, using the Tukey test $(p<0.05)$. The data that did not show normal distribution, even after transformation, were analyzed through descriptive statistics, using means and standard deviations.

\section{Results}

\section{Phenolic Acids}

Significant interactions were observed between rootstocks, trellis systems, and production cycles for gallic acid, caftaric acid, chlorogenic acid, and ferullic acid (Table 3). An isolated effect of the factor production cycle was observed for $p$-coumaric acid (Table 4). The influence of factors, such as rootstocks, trellis systems, and climatic conditions of the production season on the phenolic composition of 'Chenin Blanc' grapes corroborates the importance of characterizing and quantifying these compounds due to their bioactive nature and a correlation between these compounds and quality and typicity of their products (García-Estévez et al., 2017).

The gallic acid content was higher $\left(6.06 \mathrm{gg} \mathrm{g}^{-1}\right)$ in grapes harvested from plants grafted onto rootstock 'IAC $313^{\prime}$ trellised to VSP in cycle 2 (Table 3 ). The lowest values were observed in berries derived from vines grafted onto rootstocks 'IAC 766' and 'SO4' trellised to lyre system, evaluated in cycle 1 . There was higher accumulation of caftaric acid in berries of plants grafted onto rootstock 'SO4' (66.18 $\mu \mathrm{g} \mathrm{g}^{-1}$ ) and 'Paulsen 1103' (61.69 $\mu \mathrm{g} \mathrm{g}^{-1}$ ) with lyre trellis system in cycle 2 (Table 3). On the other hand, the lowest accumulation of caftaric acid occurred in grapes harvested in cycle 1 with lyre system and rootstock 'SO4'. The range of variation in this phenolic acid contents in both cycles, due to the association of trellis systems and rootstocks, was significant.

Chlorogenic acid accumulation was higher in grapes collected from treatments that combined root- stock 'IAC 572 ' with the VSP system in cycle 1 , rootstock 'IAC $313^{\prime}$ with the lyre system in cycle 2 , and rootstock 'Paulsen 1103' with the VSP system in cycle 2 (Table 3). The lowest values were observed in cycle 1, when 'SO4' rootstock was used in grapevines trellised to VSP system and for gallic and caftaric acid. For ferullic acid, four treatments resulted in higher contents: combinations of rootstock 'SO4' and the VSP system in cycle 1 ; 'Paulsen $1103^{\prime}$ with lyre system in cycle 1 ; and in cycle 2 , the highest contents of this phenolic acid were observed in combinations of rootstock 'IAC 313' trellised to the VSP system and of grapevines grafted onto 'SO4' trellised to lyre (Table 3). However, differences derived from the interaction between production cycle $\times$ trellis system $\times$ rootstock represented a variation of only $0.20 \mu \mathrm{g} \mathrm{g}^{-1}$.

Among the phenolic acids, only the data referring to caffeic acid did not show normal distribution. In the first production cycle, the mean content of this compound varied from $1.74 \mu \mathrm{g} \mathrm{g}^{-1}$, with the lyre system and on rootstock 'Paulsen 1103 ', to $3.14 \mu \mathrm{g} \mathrm{g}^{-1}$, on the same rootstock, but with VSP system (Table 5). In the second cycle, its accumulation was higher than in the first cycle, ranging from $2.57 \mu \mathrm{g} \mathrm{g}^{-1}$, on rootstock 'IAC 766' with the VSP system, to $7.28 \mu \mathrm{g} \mathrm{g}^{-1}$, on rootstock 'SO4' with the lyre system.

The $p$-coumaric was the phenolic acid with the most stable response and was only influenced by the production cycle (Table 4). Moreover, even considering this influence, the difference between cycles 1 and 2 has limited practical importance.

\section{Flavonoids}

Flavonoids of 'Chenin Blanc' grapes belong to three classes, namely flavan-3-ols, proanthocyanidins, and flavonols. Among flavan-3-ols, there are (-) - epicatechin gallate, $(-)$ - epigallocatechin gallate, $(+)$ - catechin, and $(-)$ - epicatechin. Among proanthocyanidins, procyanidins A2, B1, and B2 were quantified in this study. The flavonols quantified were kaempferol-3-O-glucoside, isoquercetin, isorhamnetin-3-O-glucoside, myricetin, and rutin.

Significant interactions were observed between rootstocks, trellis systems, and production cycles for (-) 
Table 3 - Contents of phenolic compounds gallic acid, caftaric acid, chlorogenic acid, ferullic acid, (-) - epicatechin, and (-) - epicatechin gallate in the berry (skin and pulp) of 'Chenin Blanc' grapes, influenced by production cycles, trellis systems, and rootstocks, in the submedium São Francisco River Valley*.

\begin{tabular}{|c|c|c|c|c|}
\hline \multirow{2}{*}{ Rootstock } & \multicolumn{2}{|c|}{ July to Oct, 2015 (Cycle 1) } & \multicolumn{2}{|c|}{ Jan to May, 2016 (Cycle 2) } \\
\hline & VSP & Lyre & VSP & Lyre \\
\hline & \multicolumn{4}{|c|}{ Gallic Acid ( $\left.\mu \mathrm{g} \mathrm{g}^{-1}\right)$} \\
\hline 'IAC 313’ & 3.64 bBb & 4.24 bAab & $6.06 \mathrm{aAa}$ & $4.92 \mathrm{aBa}$ \\
\hline 'IAC 572' & $3.70 \mathrm{bBab}$ & $4.33 \mathrm{aAa}$ & $5.33 \mathrm{aBb}$ & $4.59 \mathrm{aAa}$ \\
\hline 'IAC 766’ & $4.29 \mathrm{bAa}$ & $3.61 \mathrm{bBb}$ & $4.94 \mathrm{aAb}$ & $4.61 \mathrm{aAa}$ \\
\hline 'SO4’ & 3.94 bAab & $3.56 \mathrm{bAb}$ & $4.73 a A b$ & $4.36 \mathrm{aAa}$ \\
\hline \multirow[t]{2}{*}{ 'Paulsen 1103' } & $4.30 \mathrm{bAa}$ & 4.02 bAab & 5.15 aAb & $4.64 \mathrm{aBa}$ \\
\hline & \multicolumn{4}{|c|}{ Caftaric Acid $\left(\mu \mathrm{g} \mathrm{g}^{-1}\right)^{* *}$} \\
\hline 'IAC 313' & $13.08 \mathrm{bAb}$ & $10.31 \mathrm{bBb}$ & $37.75 \mathrm{aAa}$ & $42.59 \mathrm{aAc}$ \\
\hline 'IAC 572' & $9.46 \mathrm{bBc}$ & $17.32 \mathrm{bAa}$ & $37.66 \mathrm{aBa}$ & 51.22 aAbc \\
\hline 'IAC 766' & $12.91 \mathrm{aBb}$ & $19.25 \mathrm{bAa}$ & $14.14 \mathrm{aBc}$ & 45.79 aAc \\
\hline 'SO4’ & $21.14 \mathrm{bAa}$ & $4.81 \mathrm{bBd}$ & $26.50 \mathrm{aBb}$ & $66.18 \mathrm{aAa}$ \\
\hline \multirow[t]{2}{*}{ ‘Paulsen 1103’ } & $11.35 \mathrm{bAbc}$ & $6.77 \mathrm{bBc}$ & $31.88 \mathrm{aBab}$ & $61.69 \mathrm{aAa}$ \\
\hline & \multicolumn{4}{|c|}{ Chlorogenic Acid $\left(\mu \mathrm{g} \mathrm{g}^{-1}\right)^{\star * *}$} \\
\hline ‘IAC 313’ & 4.61 aAbc & $4.26 \mathrm{bAa}$ & $3.23 \mathrm{bBb}$ & 5.78 aAa \\
\hline 'IAC 572' & $7.55 \mathrm{aAa}$ & $3.29 \mathrm{aBab}$ & $4.46 \mathrm{bAab}$ & $3.34 \mathrm{aBb}$ \\
\hline 'IAC 766’ & $3.68 \mathrm{aAc}$ & 3.02 aAab & $4.14 \mathrm{aAab}$ & $3.33 \mathrm{aAb}$ \\
\hline 'SO4’ & 3.59 aAc & $2.33 \mathrm{aBb}$ & 3.72 aAab & $2.42 \mathrm{aBb}$ \\
\hline \multirow[t]{2}{*}{ 'Paulsen 1103’ } & 6.13 aAab & $4.33 \mathrm{aBa}$ & $5.61 \mathrm{aAa}$ & $3.04 \mathrm{bBb}$ \\
\hline & \multicolumn{4}{|c|}{ Ferullic Acid $\left(\mu g g^{-1}\right)^{* *}$} \\
\hline 'IAC 313’ & $1.78 \mathrm{bAb}$ & $1.75 \mathrm{bAa}$ & $1.92 \mathrm{aAa}$ & $1.91 \mathrm{aAab}$ \\
\hline ‘IAC 572' & 1.79 bAab & $1.78 \mathrm{bAa}$ & $1.88 \mathrm{aAab}$ & $1.83 \mathrm{aAc}$ \\
\hline 'IAC 766' & $1.78 \mathrm{aAb}$ & $1.81 \mathrm{aAa}$ & $1.81 \mathrm{aAb}$ & 1.86 aAbc \\
\hline 'SO4’ & $1.85 \mathrm{aAa}$ & $1.79 \mathrm{bBa}$ & $1.81 \mathrm{aBb}$ & $1.95 \mathrm{aAa}$ \\
\hline \multirow[t]{2}{*}{ ‘Paulsen 1103’ } & $1.75 \mathrm{bAb}$ & $1.75 \mathrm{bAa}$ & $1.83 \mathrm{aAb}$ & 1.86 aAbc \\
\hline & \multicolumn{4}{|c|}{$(-)$ - Epicatechin $\left(\mu \mathrm{g} \mathrm{g}^{-1}\right)^{\star *}$} \\
\hline 'IAC 313' & $2.37 \mathrm{bAb}$ & $2.21 \mathrm{bAb}$ & $3.68 \mathrm{aAa}$ & $2.55 \mathrm{aBd}$ \\
\hline 'IAC 572' & $2.64 \mathrm{bAa}$ & $2.42 \mathrm{bAa}$ & $3.44 \mathrm{aAb}$ & $3.04 \mathrm{aBb}$ \\
\hline 'IAC 766' & $2.44 \mathrm{aAb}$ & $2.23 \mathrm{bAb}$ & $2.68 \mathrm{aBd}$ & $3.41 \mathrm{aAa}$ \\
\hline 'SO4' & $2.67 \mathrm{bAc}$ & $1.88 \mathrm{bBd}$ & $3.34 \mathrm{aAb}$ & $2.83 \mathrm{aBc}$ \\
\hline \multirow[t]{2}{*}{ 'Paulsen 1103’ } & $2.16 \mathrm{bAd}$ & $2.03 \mathrm{bAc}$ & 3.15 aAc & $2.44 \mathrm{aBe}$ \\
\hline & \multicolumn{4}{|c|}{$(-)$ - Epicatechin Gallate $\left(\mu \mathrm{g} \mathrm{g}^{-1}\right)$} \\
\hline 'IAC 313’ & $5.99 \mathrm{aBab}$ & 5.28 aAb & 3.50 bAab & $3.83 \mathrm{bAc}$ \\
\hline 'IAC 572' & $4.78 \mathrm{aBcd}$ & $7.05 \mathrm{aAa}$ & $3.80 \mathrm{bBab}$ & $7.13 \mathrm{aAa}$ \\
\hline 'IAC 766’ & 5.34 aAbc & $5.71 \mathrm{aAb}$ & $3.28 \mathrm{bBab}$ & $4.96 \mathrm{bAb}$ \\
\hline ‘SO4’ & $6.31 \mathrm{aAa}$ & $5.51 \mathrm{aBb}$ & $4.21 \mathrm{bAa}$ & $3.82 \mathrm{bAc}$ \\
\hline ‘Paulsen 1103’ & $4.42 \mathrm{aBd}$ & $6.04 \mathrm{aAb}$ & 3.44 bBab & 4.34 bAbc \\
\hline \multicolumn{5}{|c|}{$\begin{array}{l}{ }^{*} \text { Means followed by the same lowercase letter in italics in the row do not } \\
\text { statistically differ from each other using the Tukey test }(p<0.05) \text {, comparing } \\
\text { cycles within each trellis system in interaction with each rootstock, and } \\
\text { uppercase letters, comparing the trellis systems within each cycle interacting } \\
\text { with each rootstock. In the column, means followed by the same lowercase } \\
\text { letter in bold, comparing rootstocks within each production cycle interacting } \\
\text { with each trellis system, do not statistically differ from each other using } \\
\text { the Tukey test }(p<0.05) .{ }^{* * V a r i a b l e ~ a n a l y z e d ~ w i t h ~ l o g ~}(x) \text { transformation. } \\
{ }^{* \star *} \text { Variable analyzed with } 1 / \log (x) \text { transformation. VSP = vertical shoot } \\
\text { positioning. }\end{array}$} \\
\hline
\end{tabular}

- epicatechin, (-) - epicatechin gallate, and (-) - epigallocatechin gallate. The decomposition performed in the three-way interaction analysis, due to statistical differences between mean values, showed some particular responses among the phenolic compounds of this group.
Table 4 - Content of p-coumaric acid in berries (skin and pulp) of 'Chenin Blanc' grapes in two production cycles, under the conditions of the submedium São Francisco River Valley*.

\begin{tabular}{lcc}
\hline Productive cycle & $p$-coumaric acid $\left(\mu \mathrm{g} \mathrm{g}^{-1}\right)$ & $\mathrm{CV}(\%)$ \\
\hline July to Oct, 2015 (Cycle 1) & $1.55 \mathrm{~b}$ & \\
Jan to May, 2016 (Cycle 2) & $1.59 \mathrm{a}$ & 1.61 \\
\hline${ }^{*}$ Means followed by the same letter do not differ from each other using the
\end{tabular}

${ }^{\star}$ Means followed by the same letter do not differ $f$.
Tukey test $(p<0.05)$. CV = Coefficient of variation.

The highest content of (-) - epicatechin $\left(3.68 \mu \mathrm{g} \mathrm{g}^{-1}\right)$ in berries was observed when rootstock 'IAC 313' was used with the VSP system in cycle 2, and the lowest content was observed in cycle 1 in rootstock 'SO4' with the lyre system (Table 3). With the lyre system, the highest content was observed in berries collected in cycle 2 from plants grafted onto 'IAC 766'. The highest contents of (-) - epicatechin gallate were observed when rootstock 'IAC 572' was trellised to the lyre system in both cycles evaluated. The lowest contents were observed in cycle 2 on rootstocks 'IAC 766', 'Paulsen 1103', and 'IAC 572' trellised to the VSP system in the same cycle (Table 3). Accumulation of (-) - epigallocatechin gallate was higher $\left(12.19 \mathrm{~g} \mathrm{~g} \mathrm{~g}^{-1}\right)$ in berries of plants grafted onto 'IAC 313' trellised to lyre system in cycle 2 (Table 6 ). For the treatment with this rootstock, as well as rootstocks 'IAC 572' and 'SO4', cycle 2 resulted in higher contents, with both trellis systems, compared to those observed in the previous cycle. On the other hand, the lowest content was observed for rootstock 'IAC 766' with the VSP system in cycle 1 .

The flavonols also comprise the flavonoids class. In 'Chenin Blanc' grapes, there was interaction between rootstocks, trellis systems, and production cycles for flavonols kaempferol-3-O-glucoside, isorhamnetin-3-O-glucoside, and rutin. Due to decomposition performed in the significant three-way interaction analysis, the highest content of kaempferol-3-O-glucoside was recorded for the combination of rootstock 'IAC 766 ' with the lyre system in cycle 1 , which was distinguished from the others (Table 6). The use of rootstock 'SO4' associated to the VSP system in cycle 2 resulted in a lower content of this compound in 'Chenin Blanc' grapes. Evaluating the phenolic composition of 'Alicante', 'Black Malvasia', 'Nerello' and 'Prunesta' red grapes cultivated on the southern coast of Italy, Giuffrè (2013) determined kaempferol-3-O-glucoside contents of only $0.54 ; 7.35 ; 2.80$ and $2.55 \mathrm{mg} \mathrm{kg}^{-1}$, respectively. For isorhamnetin-3-O-glucoside, the use of rootstock 'SO4' with the VSP system in cycle 1 promoted the highest accumulation in grapes of the scion cultivar (Table 6). On the other hand, when rootstock 'Paulsen 1103' was adopted with the VSP system in cycle 2 , grapes were characterized by a lower content of this compound. Regarding rutin, the highest accumulation $\left(4.07 \mathrm{\mu g} \mathrm{g}^{-1}\right)$ in grapes of the scion cultivar was observed with grapevines grafted onto rootstock 'SO4' trellised to lyre system in cycle 2 , whereas the lowest 
Table 5 - Mean values and standard deviations of phenolic compounds caffeic acid, $(+)$ - catechin, procyanidin A2, procyanidin B2, isoquercetin and myricetin in berries (skin and pulp) of 'Chenin Blanc' grapes, influenced by production cycles, trellis systems, and rootstocks in the submedium São Francisco River Valley*.

\begin{tabular}{|c|c|c|c|c|}
\hline \multirow{2}{*}{ Rootstock } & \multicolumn{2}{|c|}{ July to Oct, 2015 (Cycle 1) } & \multicolumn{2}{|c|}{ Jan to May, 2016 (Cycle 2) } \\
\hline & Vertical Shoot Positioning & Lyre & Vertical Shoot Positioning & Lyre \\
\hline & \multicolumn{4}{|c|}{ Caffeic Acid $\left(\mu \mathrm{g} \mathrm{g}^{-1}\right)$} \\
\hline 'IAC 313’ & $2.28 \pm 0.19$ & $2.17 \pm 0.18$ & $6.59 \pm 0.31$ & $6.77 \pm 0.38$ \\
\hline 'IAC 572’ & $2.22 \pm 0.24$ & $1.90 \pm 0.14$ & $6.21 \pm 0.32$ & $6.99 \pm 0.27$ \\
\hline 'IAC 766’ & $2.54 \pm 0.38$ & $2.51 \pm 0.54$ & $2.57 \pm 0.42$ & $5.67 \pm 1.08$ \\
\hline ‘SO4’ & $2.72 \pm 0.18$ & $1.99 \pm 0.13$ & $4.22 \pm 0.81$ & $7.28 \pm 0.41$ \\
\hline \multirow[t]{2}{*}{ ‘Paulsen 1103’ } & $3.14 \pm 0.07$ & $1.74 \pm 0.08$ & $4.60 \pm 0.29$ & $5.96 \pm 0.66$ \\
\hline & \multicolumn{4}{|c|}{$(+)$ - Catechin $\left(\mu \mathrm{g} \mathrm{g}^{-1}\right)$} \\
\hline 'IAC 313’ & $5.09 \pm 1.25$ & $4.21 \pm 0.26$ & $5.59 \pm 0.32$ & $6.30 \pm 0.42$ \\
\hline ‘IAC 572’ & $5.29 \pm 0.72$ & $4.58 \pm 0.28$ & $5.67 \pm 0.37$ & $5.49 \pm 0.44$ \\
\hline 'IAC 766’ & $4.65 \pm 0.77$ & $4.69 \pm 0.86$ & $5.88 \pm 0.39$ & $5.51 \pm 0.84$ \\
\hline ‘SO4’ & $4.15 \pm 0.30$ & $3.61 \pm 0.18$ & $5.45 \pm 0.45$ & $4.16 \pm 1.07$ \\
\hline \multirow[t]{2}{*}{ ‘Paulsen 1103’ } & $3.18 \pm 0.14$ & $4.16 \pm 0.18$ & $5.96 \pm 0.42$ & $3.68 \pm 0.28$ \\
\hline & \multicolumn{4}{|c|}{ Procyanidin A2 $\left(\mu \mathrm{g} \mathrm{g}^{-1}\right)$} \\
\hline 'IAC 313’ & $2.35 \pm 0.03$ & $2.36 \pm 0.04$ & $2.35 \pm 0.03$ & $2.32 \pm 0.01$ \\
\hline ‘IAC 572’ & $2.32 \pm 0.00$ & $2.34 \pm 0.02$ & $2.35 \pm 0.03$ & $2.32 \pm 0.00$ \\
\hline 'IAC 766’ & $2.32 \pm 0.02$ & $2.36 \pm 0.02$ & $2.35 \pm 0.05$ & $2.35 \pm 0.03$ \\
\hline ‘SO4’ & $2.33 \pm 0.01$ & $2.33 \pm 0.01$ & $2.38 \pm 0.01$ & $2.35 \pm 0.01$ \\
\hline \multirow[t]{2}{*}{ ‘Paulsen 1103’ } & $2.32 \pm 0.01$ & $2.33 \pm 0.02$ & $2.35 \pm 0.03$ & $2.33 \pm 0.01$ \\
\hline & \multicolumn{4}{|c|}{ Procyanidin B2 $\left(\mu \mathrm{g} \mathrm{g}^{-1}\right)$} \\
\hline ‘IAC 313’ & $1.86 \pm 0.26$ & $1.68 \pm 0.17$ & $1.79 \pm 0.17$ & $1.31 \pm 0.11$ \\
\hline ‘IAC 572’ & $1.16 \pm 0.20$ & $1.82 \pm 0.13$ & $1.66 \pm 0.20$ & $1.58 \pm 0.10$ \\
\hline 'IAC 766’ & $1.18 \pm 0.26$ & $1.81 \pm 0.23$ & $1.85 \pm 0.14$ & $1.85 \pm 0.17$ \\
\hline ‘SO4’ & $1.45 \pm 0.21$ & $1.71 \pm 0.04$ & $1.80 \pm 0.50$ & $1.56 \pm 0.42$ \\
\hline \multirow[t]{2}{*}{ 'Paulsen 1103' } & $0.71 \pm 0.02$ & $1.71 \pm 0.04$ & $1.70 \pm 0.17$ & $1.27 \pm 0.17$ \\
\hline & \multicolumn{4}{|c|}{ Isoquercetin $\left(\mu \mathrm{g} \mathrm{g}^{-1}\right)$} \\
\hline 'IAC 313’ & $37.89 \pm 6.47$ & $61.51 \pm 4.79$ & $37.44 \pm 2.87$ & $35.12 \pm 1.23$ \\
\hline ‘IAC 572’ & $37.84 \pm 4.44$ & $67.58 \pm 1.55$ & $33.37 \pm 3.66$ & $23.51 \pm 2.62$ \\
\hline 'IAC 766’ & $35.66 \pm 4.01$ & $66.04 \pm 2.11$ & $27.14 \pm 3.74$ & $36.93 \pm 3.39$ \\
\hline ‘SO4’ & $52.87 \pm 3.16$ & $54.25 \pm 5.48$ & $41.33 \pm 2.12$ & $61.39 \pm 3.72$ \\
\hline \multirow[t]{2}{*}{ ‘Paulsen 1103’ } & $60.44 \pm 0.56$ & $47.43 \pm 2.81$ & $26.89 \pm 2.47$ & $40.88 \pm 4.16$ \\
\hline & \multicolumn{4}{|c|}{ Myricetin $\left(\mu \mathrm{g} \mathrm{g}^{-1}\right)$} \\
\hline 'IAC 313’ & $2.63 \pm 0.02$ & $2.74 \pm 0.06$ & $2.62 \pm 0.05$ & $2.61 \pm 0.02$ \\
\hline ‘AC 572’ & $2.53 \pm 0.11$ & $2.84 \pm 0.03$ & $2.63 \pm 0.02$ & $2.59 \pm 0.02$ \\
\hline 'IAC 766’ & $2.64 \pm 0.13$ & $2.80 \pm 0.06$ & $2.64 \pm 0.04$ & $2.62 \pm 0.05$ \\
\hline ‘SO4’ & $2.64 \pm 0.04$ & $2.78 \pm 0.03$ & $2.57 \pm 0.04$ & $2.66 \pm 0.03$ \\
\hline ‘Paulsen 1103’ & $2.84 \pm 0.04$ & $2.61 \pm 0.11$ & $2.56 \pm 0.02$ & $2.60 \pm 0.01$ \\
\hline
\end{tabular}

${ }^{\star}$ Data did not show normal distribution.

content was observed in cycle 1, using rootstock 'IAC $313^{\prime}$ with VSP system (Table 6).

Among flavan-3-ols, $(+)$ - catechin was the only compound whose data did not have normal distribution (Table 5). In the first cycle, the accumulation of $(+)$ catechin ranged from the mean content of $3.18 \mu \mathrm{g} \mathrm{g}^{-1}$, in plants with the VSP system and on rootstock 'Paulsen $1103^{\prime}$, to $5.29 \mu \mathrm{g} \mathrm{g}^{-1}$, when the VSP system was associated to 'IAC 572 '. In cycle 2 , mean contents of 'Chenin Blanc' grapes ranged from $3.68 \mu \mathrm{g} \mathrm{g}^{-1}$, on rootstock 'SO4' with lyre system, to $6.30 \mu \mathrm{g} \mathrm{g}^{-1}$, on rootstock 'IAC 313 ' with lyre system.

The data observed for procyanidin A2 and B2 did not show normal distribution. The mean contents of pro- cyanidin A2 in production cycle 1 varied from $2.32 \mu \mathrm{g} \mathrm{g}^{-1}$ in grapes from plants trellised to the VSP system combined with rootstocks 'IAC 572', 'IAC 766', and 'SO4', to $2.36 \mu \mathrm{g} \mathrm{g}^{-1}$ with the lyre system on rootstock 'IAC 313' (Table 5). In cycle 2, the contents of procyanidin A2 varied approximately within the same range, with equivalent values to contents in scion grapes. Accumulation of procyanidin B2 was lower than that of procyanidin A2, ranging, in cycle 1 , from $0.71 \mu \mathrm{g} \mathrm{g}^{-1}$, with the VSP system in combination with rootstock 'Paulsen 1103 ', to $1.86 \mu \mathrm{g}$ $\mathrm{g}^{-1}$, with the VSP system and 'IAC 313' (Table 5). In cycle 2 , the maximum accumulation potential was equal to that of the first cycle and to accumulations in treatments that combined rootstock 'IAC 766' with both trellis systems. 
Table 6 - Contents of phenolic compounds (-) - epigallocatechin gallate, kaempferol-3-0-glucoside, isorhamnetin-3-0-glucoside, rutin and viniferin in the berry (skin and pulp) of 'Chenin Blanc' grapes, influenced by production cycles, trellis systems, and rootstocks, in the submedium São Francisco River Valley*.

\begin{tabular}{|c|c|c|c|c|}
\hline \multirow{2}{*}{ Rootstock } & \multicolumn{2}{|c|}{ July to Oct, 2015 (Cycle 1) } & \multicolumn{2}{|c|}{ Jan to May, 2016 (Cycle 2) } \\
\hline & Vertical Shoot Positioning & Lyre & Vertical Shoot Positioning & Lyre \\
\hline & \multicolumn{4}{|c|}{$(-)$ - Epigallocatechin Gallate $\left(\mu \mathrm{g} \mathrm{g}^{-1}\right)$} \\
\hline 'IAC 313” & $8.29 \mathrm{bBa}$ & 9.88 bAa & $10.43 \mathrm{aBa}$ & $12.19 \mathrm{aAa}$ \\
\hline 'IAC 572’ & 7.56 bBab & 9.14 bAa & $9.23 \mathrm{aBa}$ & 10.42 aAb \\
\hline 'IAC 766' & $6.92 \mathrm{bBb}$ & $9.34 \mathrm{aAa}$ & $10.41 \mathrm{aAa}$ & $9.69 \mathrm{aAb}$ \\
\hline ‘S04’ & 7.79 bBab & $8.90 \mathrm{bAa}$ & 9.73 aAa & 10.27 aAb \\
\hline \multirow[t]{2}{*}{ ‘Paulsen 1103’ } & 7.49 bBab & $9.50 \mathrm{aAa}$ & $9.26 \mathrm{aBa}$ & $10.29 \mathrm{aAb}$ \\
\hline & \multicolumn{4}{|c|}{ Kaempferol-3-0-glucoside ( $\left.\mu \mathrm{g} \mathrm{g}^{-1}\right)^{\star *}$} \\
\hline 'IAC 313' & $14.50 \mathrm{aBd}$ & 19.11 aAc & $14.20 \mathrm{aAb}$ & $12.57 \mathrm{bAc}$ \\
\hline 'IAC 572' & $18.82 \mathrm{aAc}$ & $12.75 \mathrm{aBd}$ & $12.76 \mathrm{bAb}$ & $12.31 \mathrm{aAc}$ \\
\hline 'IAC 766' & $35.15 \mathrm{aBa}$ & $55.54 \mathrm{aAa}$ & $22.55 \mathrm{bAa}$ & $25.48 \mathrm{bAa}$ \\
\hline ‘SO4’ & $23.71 \mathrm{aBb}$ & 35.23 aAb & $6.23 \mathrm{bBd}$ & $18.19 \mathrm{bAb}$ \\
\hline \multirow[t]{2}{*}{ ‘Paulsen 1103’ } & $32.26 \mathrm{aAa}$ & $20.05 \mathrm{aBc}$ & $8.49 b B c$ & $15.51 \mathrm{bAb}$ \\
\hline & \multicolumn{4}{|c|}{ Isorhamnetin-3-0-glucoside $\left(\mu \mathrm{g} \mathrm{g}^{-1}\right)^{\star \star *}$} \\
\hline 'IAC 313’ & $2.36 \mathrm{aAb}$ & $2.39 \mathrm{aAab}$ & $2.18 \mathrm{aAa}$ & $2.05 \mathrm{bAa}$ \\
\hline 'IAC 572’ & $2.46 \mathrm{aAb}$ & $2.23 \mathrm{aAb}$ & $1.98 \mathrm{bAa}$ & $2.00 \mathrm{aAa}$ \\
\hline 'IAC 766' & 2.62 aAab & $2.71 \mathrm{aAa}$ & 2.23 bAa & $2.15 \mathrm{bAa}$ \\
\hline ‘SO4’ & 3.00 aAa & $2.80 \mathrm{aAa}$ & $1.95 \mathrm{bBa}$ & $2.40 \mathrm{bAa}$ \\
\hline \multirow[t]{2}{*}{ ‘Paulsen 1103’ } & $2.60 \mathrm{aAab}$ & $2.79 \mathrm{aAa}$ & $1.91 \mathrm{bBa}$ & $2.26 \mathrm{bAa}$ \\
\hline & \multicolumn{4}{|c|}{ Rutin $\left(\mu \mathrm{g} \mathrm{g}^{-1}\right)^{\star *}$} \\
\hline 'IAC 313' & $1.85 \mathrm{bBc}$ & $2.63 \mathrm{aAa}$ & $3.97 \mathrm{aAa}$ & $2.56 \mathrm{aBb}$ \\
\hline 'IAC 572' & 2.02 bAbc & $2.57 \mathrm{aAa}$ & $3.79 \mathrm{aAa}$ & $2.35 \mathrm{aBb}$ \\
\hline 'IAC 766’ & $2.44 \mathrm{bBab}$ & $2.91 \mathrm{aAa}$ & $3.60 \mathrm{aAa}$ & $2.35 \mathrm{bBb}$ \\
\hline ‘SO4’ & 2.31 bAabc & $2.30 \mathrm{bAa}$ & $3.22 \mathrm{aBa}$ & $4.07 \mathrm{aAa}$ \\
\hline \multirow[t]{2}{*}{ ‘Paulsen 1103’ } & $2.97 \mathrm{bAa}$ & $2.41 \mathrm{aBa}$ & $3.53 \mathrm{aAa}$ & $2.71 \mathrm{aBb}$ \\
\hline & \multicolumn{4}{|c|}{ Viniferin $\left(\mu \mathrm{g} \mathrm{g}^{-1}\right)$} \\
\hline 'IAC 313’ & $2.38 \mathrm{bAa}$ & $2.36 \mathrm{aAa}$ & $2.46 \mathrm{aAa}$ & $2.35 \mathrm{aBa}$ \\
\hline ‘IAC 572’ & $2.39 \mathrm{aAa}$ & $2.32 \mathrm{aAa}$ & 2.29 bBb & $2.37 \mathrm{aAa}$ \\
\hline 'IAC 766' & $2.38 \mathrm{aAa}$ & $2.33 \mathrm{aAa}$ & $2.36 \mathrm{aAb}$ & $2.32 \mathrm{aAa}$ \\
\hline 'SO4’ & $2.38 \mathrm{aAa}$ & $2.33 \mathrm{aAa}$ & $2.34 \mathrm{aAb}$ & $2.39 \mathrm{aAa}$ \\
\hline ‘Paulsen 1103’ & $2.45 \mathrm{aAa}$ & $2.39 \mathrm{aAa}$ & $2.34 \mathrm{bAb}$ & $2.33 \mathrm{aAa}$ \\
\hline
\end{tabular}

There was a two-way interaction effect of production cycle and trellis systems and of rootstocks and trellis systems on contents of procyanidin B1 in 'Chenin Blanc' grapes (Table 7). The interaction between production cycles and trellis systems indicated lower procyanidin B1 contents in 'Chenin Blanc' grapes in cycle 2 , with a slight advantage towards the lyre system $\left(6.38 \mu \mathrm{g} \mathrm{g}^{-1}\right)$. The lowest content was observed in grapes produced with the VSP system in cycle 1 . On the other hand, the interaction between rootstock and trellis systems allowed to recognize the highest potential of procyanidin B1 accumulation in the lyre system when plants were grafted onto rootstock 'IAC 572 '.

Data on contents of flavonols isoquercetin and myricetin did not have normal distribution (Table 5). In cycle 1 , the accumulation of isoquercetin ranged from
$37.88 \mu \mathrm{g} \mathrm{g}^{-1}$, on rootstock 'IAC $313^{\prime}$ with the VSP system, to $67.58 \mu \mathrm{g} \mathrm{g}^{-1}$, on rootstock 'IAC 572 ' with the lyre system. In cycle 2 , contents ranged from $23.51 \mu \mathrm{g} \mathrm{g}^{-1}$, with the combination of lyre system with rootstock 'IAC 572', to $61.39 \mu \mathrm{g} \mathrm{g}^{-1}$, with lyre system combined to rootstock 'SO4'. Among the phenolic compounds determined in production cycle 2 , isoquercetin and caftaric acid stood out, as isoquercetin had the highest accumulation in 'Chenin Blanc' grapes. Regarding the compound myricetin, in cycle 1, 'Chenin Blanc' grapes ranged from 2.53

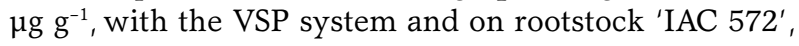
to $2.84 \mu \mathrm{g} \mathrm{g}^{-1}$, with the lyre system and on rootstock 'Paulsen 1103' (Table 5). In cycle 2, myricetin accumulation, based on the mean contents observed, ranged from $2.56 \mu \mathrm{g} \mathrm{g}^{-1}$ using rootstock 'IAC 1103 'trellised to the VSP system, to $2.66 \mu \mathrm{g} \mathrm{g}^{-1}$, on rootstock 'SO4' with the lyre system. 


\section{Stilbenes}

A significant interaction was observed between rootstocks, trellis systems, and production cycles only for viniferin (Table 6). However, differences were related to cycle 2 when plants grafted onto 'IAC 313' trellised to the VSP system promoted higher viniferin content in grapes of the scion cultivar. On the other hand, the lowest values were observed both in cycle 1 , on rootstock 'IAC 572' in combination with the lyre system, and in cycle 2 , on 'IAC $766^{\prime}$ with the lyre system. However, differences in the contents of this compound in grapes were limited, and whether they actually have an impact on the protection of tissues to stressful conditions is yet to be evaluated.

The data on other quantified stilbenes, cis-resveratrol, trans-resveratrol, and piceatannol, did not have normal distribution (Table 8). The contents of these stilbenes were lower than those observed for viniferin. In cycle 1, cis-resveratrol accumulation ranged from 1.45 $\mu \mathrm{g} \mathrm{g}^{-1}$ in the combination between the VSP system and rootstock 'IAC 766 ', to $2.11 \mathrm{\mu g} \mathrm{g}^{-1}$, in grapes harvested from plants on rootstock 'IAC 313' trellised to the lyre system. In cycle 2, cis-resveratrol accumulation was lower; the highest mean values were lower than the lowest mean content recorded in cycle 1 . Regarding trans-resveratrol and piceatannol accumulation, little influence from the factors studied was observed. For trans-resveratrol, in cycle 1, mean contents ranged from $1.57 \mu \mathrm{g} \mathrm{g}^{-1}$, on rootstock 'Paulsen 1103' with the VSP system, to 1.67 $\mu \mathrm{g} \mathrm{g}^{-1}$, in the treatment combining the lyre system with 'IAC 766'. In cycle 2, this accumulation ranged from 1.57 $\mu \mathrm{g} \mathrm{g}^{-1}$, with VSP system associated to rootstock 'Paulsen $1103^{\prime}$ and lyre system combined with 'IAC 313', 'IAC 572 , to $1.61 \mu \mathrm{g} \mathrm{g}^{-1}$, content observed in grapes harvested from plants grafted onto 'SO4' trellised to lyre.

Table 7 - Content of procyanidin B1 ( $\mu \mathrm{g} \mathrm{g}^{-1}$ ) in berries (skin and pulp) of 'Chenin Blanc' grapes in two production cycles and with two trellis systems, on five rootstocks, under the conditions of the submedium São Francisco River Valley.

\begin{tabular}{|c|c|c|c|c|c|c|}
\hline \multirow{2}{*}{ Productive cycle } & \multicolumn{5}{|c|}{ Trellis system* } & \multirow{2}{*}{ CV } \\
\hline & \multicolumn{3}{|c|}{ Vertical Shoot Positioning } & \multicolumn{2}{|c|}{ Lyre } & \\
\hline & \multirow{2}{*}{\multicolumn{3}{|c|}{$4.57 \mathrm{bB}$}} & \multirow{2}{*}{\multicolumn{2}{|c|}{$6.09 \mathrm{bA}$}} & \multirow{3}{*}{3.13} \\
\hline July to Oct, 2015 (Cycle 1) & & & & & & \\
\hline Jan to May, 2016 (Cycle 2) & & $6.34 \mathrm{aA}$ & & & & \\
\hline \multirow{2}{*}{ Trellis system } & \multicolumn{5}{|c|}{ Rootstock $^{* *}$} & \\
\hline & 'IAC 313' & 'IAC 572' & 'IAC 766' & 'SO4' & 'Paulsen 1103' & \\
\hline Vertical Shoot Positioning & $5.72 \mathrm{aA}$ & $5.20 \mathrm{bA}$ & $5.32 \mathrm{bA}$ & $5.42 \mathrm{aA}$ & $5.63 \mathrm{aA}$ & \multirow{2}{*}{10.05} \\
\hline Lyre & $5.69 \mathrm{aC}$ & $7.16 \mathrm{aA}$ & $6.92 \mathrm{aAB}$ & $6.02 \mathrm{aBC}$ & $5.38 \mathrm{aC}$ & \\
\hline
\end{tabular}

${ }^{*}$ Means followed by the same lowercase or uppercase letter do not differ from each other using the Tukey test $(p<0.05)$ regarding production cycles and trellis systems, respectively. * * Means followed by the same lowercase or uppercase letter do not differ from each other using the Tukey test $(p<0.05)$ regarding trellis systems and rootstocks, respectively; $\mathrm{CV}=$ Coefficient of variation.

Table 8 - Mean values and standard deviations of phenolic compounds cis-resveratrol, trans-resveratrol and piceatannol in berries (skin and pulp) of 'Chenin Blanc' grapes, influenced by production cycles, trellis systems, and rootstocks in the submedium São Francisco River Valley*.

\begin{tabular}{|c|c|c|c|c|}
\hline \multirow{2}{*}{ Rootstock } & \multicolumn{2}{|c|}{ July to Oct, 2015 (Cycle 1) } & \multicolumn{2}{|c|}{ Jan to May, 2016 (Cycle 2) } \\
\hline & Vertical Shoot Positioning & Lyre & Vertical Shoot Positioning & Lyre \\
\hline & \multicolumn{4}{|c|}{ Cis-resveratrol $\left(\mu \mathrm{g} \mathrm{g}^{-1}\right)$} \\
\hline 'IAC 313’ & $1.71 \pm 0.02$ & $2.40 \pm 0.15$ & $1.30 \pm 0.18$ & $0.92 \pm 0.04$ \\
\hline ‘IAC 572' & $1.66 \pm 0.13$ & $1.69 \pm 0.04$ & $1.18 \pm 0.08$ & $0.84 \pm 0.06$ \\
\hline 'IAC 766’ & $1.45 \pm 0.13$ & $2.11 \pm 0.40$ & $1.18 \pm 0.08$ & $0.88 \pm 0.04$ \\
\hline ‘SO4’ & $1.57 \pm 0.10$ & $1.85 \pm 0.08$ & $1.25 \pm 0.28$ & $0.91 \pm 0.07$ \\
\hline \multirow[t]{2}{*}{ ‘Paulsen 1103’ } & $1.75 \pm 0.04$ & $1.98 \pm 0.30$ & $0.95 \pm 0.09$ & $0.87 \pm 0.03$ \\
\hline & \multicolumn{4}{|c|}{ Trans-resveratrol $\left(\mu \mathrm{g} \mathrm{g}^{-1}\right)$} \\
\hline 'IAC 313' & $1.60 \pm 0.00$ & $1.64 \pm 0.01$ & $1.59 \pm 0.02$ & $1.57 \pm 0.00$ \\
\hline ‘IAC 572’ & $1.59 \pm 0.02$ & $1.62 \pm 0.01$ & $1.58 \pm 0.01$ & $1.57 \pm 0.01$ \\
\hline 'IAC 766’ & $1.61 \pm 0.03$ & $1.67 \pm 0.03$ & $1.59 \pm 0.03$ & $1.59 \pm 0.02$ \\
\hline ‘SO4’ & $1.61 \pm 0.01$ & $1.65 \pm 0.01$ & $1.58 \pm 0.02$ & $1.61 \pm 0.02$ \\
\hline \multirow[t]{2}{*}{ 'Paulsen 1103' } & $1.57 \pm 0.01$ & $1.62 \pm 0.01$ & $1.57 \pm 0.01$ & $1.58 \pm 0.01$ \\
\hline & \multicolumn{4}{|c|}{ Piceatannol $\left(\mu \mathrm{g} \mathrm{g}^{-1}\right)$} \\
\hline 'IAC 313’ & $1.63 \pm 0.01$ & $1.61 \pm 0.01$ & $1.63 \pm 0.01$ & $1.61 \pm 0.00$ \\
\hline ‘IAC 572’ & $1.63 \pm 0.01$ & $1.63 \pm 0.01$ & $1.63 \pm 0.01$ & $1.64 \pm 0.01$ \\
\hline 'IAC 766’ & $1.64 \pm 0.04$ & $1.62 \pm 0.02$ & $1.62 \pm 0.03$ & $1.67 \pm 0.02$ \\
\hline 'SO4’ & $1.71 \pm 0.07$ & $1.62 \pm 0.02$ & $1.66 \pm 0.05$ & $1.64 \pm 0.01$ \\
\hline ‘Paulsen 1103’ & $1.62 \pm 0.00$ & $1.62 \pm 0.01$ & $1.61 \pm 0.01$ & $1.64 \pm 0.01$ \\
\hline
\end{tabular}


On the other hand, variation in piceatannol content was small, ranging from $1.61 \mathrm{\mu g} \mathrm{g}^{-1}$ to $1.71 \mathrm{\mu g} \mathrm{g}^{-1}$, which does not emphasize cycle, the trellis system, or rootstock as effective stimulating or inhibiting factors for synthesis. However, when compared to cis-resveratrol and transresveratrol in cycle 2 , the highest accumulation was in the piceatannol compound.

\section{Discussion}

In this study, discussions were based on understanding the effects of the trellis system, rootstocks and climatic conditions of the growing region that influence accumulation of phenolic compounds in berries, since information in scarce on these compounds for white cultivars, such as 'Chenin Blanc', in tropical conditions.

Climate variations are particularly important in grapevine cultivation, since temperature and sunlight intensity are some factors that trigger environmental stresses, dramatically affecting the phenolic metabolism. In this regard, canopy management from the choice of the trellis system and rootstock can be optimized to adjust grape berry quality and its products (Teixeira et al., 2013).

\section{Factors that influence accumulation of phenolic acids}

Gallic acid provides effective protection against oxidative damages caused by reactive species of oxygen, including radicals hydroxyl $\left(\mathrm{HO}^{*}\right)$, superoxide $\left(\mathrm{O}_{2}^{-{ }^{-}}\right)$, and peroxyl $\left(\mathrm{ROO}^{\circ}\right)$, and non-radicals, hydrogen peroxide $\left(\mathrm{H}_{2} \mathrm{O}_{2}\right)$ and hypochlorous acid $(\mathrm{HOCl})$, which are responsible for oxidative stress. Oxidative damage to macromolecules, such as DNA, proteins, and lipids, causes aging, degenerative diseases, cerebral dysfunction, cardiovascular and inflammatory diseases, and cancer, and gallic acid is an important antioxidant component responsible for effective anti-radical and anti-cancer activity. The gallic acid content is affected by external stimuli, such as solar radiation and temperature, similar to other phenolic compounds in grapes (Badhani et al., 2015). Therefore, a single factor cannot be associated to this response. The VSP trellis system with the rootstock 'IAC $313^{\prime}$ in cycle 2 must have provided an appropriate exposure of the berries to solar radiation, improving the accumulation of the gallic acid.

Phenylalanine ammonia-lyase (PAL) is the key enzyme responsible for catalyzing the conversion of phenylalanine into trans-cinnamic acid, the first step for biosynthesis of simple phenylpropanoids, such as $p$-coumaric acid, caftaric acid, and ferullic acid (Camm and Towers, 1973). The PAL activity seems to be quite sensitive to the physiological state of the plant. Among environmental factors, changes in the PAL activity occur due to sunlight action. The increase in phenolic compound contents is related to the positive regulation of sunlight on proteins involved in the biosynthesis path of these compounds (Wang et al., 2015), corroborating the highest caftaric acid and ferullic acid contents observed in the second production cycle using rootstock 'SO4' with the lyre system. This response is justified since the canopy disposition in the lyre system allows better capture of sunlight. On the other hand, lower vigor, admittedly associated to rootstock 'SO4', also explains the accumulation of these compounds.

In addition, the higher accumulation of simple phenylpropanoids, such as $p$-coumaric acid, ferullic acid, and caffeic acid in cycle 2 is possibly related to the predisposition to defend plant tissues from the conditions that lead to increased free radicals due to cell metabolism. Free radicals accumulate especially under environmental stresses (Wang et al., 2017). Therefore, the highest mean temperatures in cycle 2 , along with the lower range of values in this period, are a predisposing factor to increase these radicals.

Different responses were observed between trellis systems, according to the production cycle and rootstocks evaluated. Effectiveness of each system within each production cycle should be considered, resulting in differentiated responses according to the year season, mainly regarding absorption of solar radiation by the canopy. Padilha et al. (2017) evaluated the phenolic profile in grapevines for juice production and observed higher accumulation of phenolics in edaphoclimatic conditions of the tropical semi-arid region due to high incidence of solar radiation.

Our findings show that chlorogenic acid had higher accumulation in production cycle 1 with the VSP system and rootstock 'IAC-572'. The high incidence of solar radiation in this cycle caused the same result observed by the authors cited previously, emphasizing that the VSP system, due to canopy disposition, along with the use of high-vigor rootstock 'IAC-572', may have protected berries from the direct radiation and prevented more accumulation of phenolic compounds.

Alternation of results between consecutive production cycles is common in systems with harvests in two seasons of the same year. Although climatic conditions were different in both seasons of the year, there is lack of stability in the productive load of plants across successive cycles (Leão et al., 2016), corroborating the differential accumulation behavior of phenolic compounds in each cycle.

\section{Factors that influence accumulation of flavonoids}

Relative air humidity ( $\mathrm{RH})$ influences the synthesis of flavonoids. When RH is low, there is deficit of vapor pressure, resulting in reduced transpiration and photosynthesis, affecting growth, and subsequently, accumulation of these compounds (Vogt et al., 1994). This assumption confirms the lower accumulation of $(-)$ - epicatechin, (-) - epicatechin gallate, (-) - epigallocatechin gallate, and rutin in cycle 1 , characterized by lower $\mathrm{RH}$.

The impact of sunlight and temperature in grape composition is particularly interesting for synthesis of flavonoids. Temperature of the berry influences the activity of flavonoid-3', $5^{\prime}$-hydroxylase and flavonoid-3'- 
hydroxylase, inducing changes in accumulation of flavonoids (Downey et al., 2004). Very high temperatures $\left(30-35^{\circ} \mathrm{C}\right)$ are considered to potentially interfere with metabolic processes that reduce accumulation of flavonoids (Hickey et al., 2018). In this study, at the end of production cycle 1 , in the stage of berry maturation and phenolic compound accumulation, a higher temperature $\left(35.3^{\circ} \mathrm{C}\right)$ was observed, justifying lower accumulation of (-) - epicatechin, (-) - epigallocatechin gallate, rutin, and procyanidin $\mathrm{B} 1$.

In addition to atmospheric conditions, particularities in the microclimate of the vineyard may influence metabolism of grapes. However, studies conducted in the same area and period of this work indicated that the microclimate in the vineyard was very similar to both trellis systems, except for the photosynthetically active radiation on bunches (Lira et al., 2017).

Among the flavan-3-ols detected, (-) - epigallocatechin gallate was the compound with the highest contents in its class. In a study conducted by Rebello et al. (2013), (+) - catechin was the flavan-3-ol with the highest contents in 'BRS Violeta' grapes produced in a Brazilian subtropical region. Local cultivation conditions are known to affect the synthesis and accumulation of secondary metabolites, namely flavan-3-ols. These compounds are directly related to organoleptic properties, such as astringency and bitterness. These properties are related to phenolic composition, which is influenced by climatic and crop conditions, and are therefore important factors to ensure quality of grapes and their products (García-Estévez et al., 2017).

The observed results confirmed that phenolic composition is associated to local cultivation conditions, as well as to vineyard management, providing an adequate exposure of the fruit to sunlight, which may determine accumulation of bioactive compounds in wine grape cultivars, according to Hickey et al. (2018).

Dias et al. (2012) evaluated the phenolic composition in the skin of grapes from grapevines grafted onto rootstocks 'SO4', 'Paulsen 1103', and 'Richter 110', and observed no differences. However, the authors stated that the less vigorous rootstocks, such as rootstock 'SO4', tended to accumulate more phenolic compounds. This might explain the differences between rootstocks found in this study and justify the fact that grapevines grafted onto 'SO4' and trellised to the lyre system in cycle 2 had a higher amount of rutin and isoquercetin, and some phenolic acids, such as caftaric acid, ferullic acid, and caffeic acid.

Exposure to sunlight is the main factor that explains accumulation of phenolic compounds (Padilha et al., 2017). Therefore, exposure of bunches to solar radiation provided by the lyre system in grapevines grafted onto rootstocks 'IAC 766 ' and 'SO4' is related to the increased concentration of kaempferol-3-O-glucoside present in 'Chenin Blanc' grapes. According to Katerji et al. (1994), grapevines trellised to the lyre system have a higher accumulation of phenolic compounds, as this trellis system promotes a moderate stress on the grapevine by exposing its foliage to radiation. However, our results show that this behavior is valid only for specific groups of phenolic compounds and depends both on climatic conditions, which characterize the productive cycle, and the rootstock adopted.

Rutin, besides a high antioxidant activity, has several pharmacological functions, such as vasoprotective, anti-proliferative, antithrombotic, and cardioprotector properties. Isoquercetin is a powerful antioxidant in grapevines and has been extensively investigated for its antioxidant, cytoprotective, vasoprotective, antiproliferative, and anti-inflammatory properties, with great capacity to clean free radicals and power to neutralize highly reactive species (Cruz-Zúñiga et al., 2016). On the other hand, isoquercetin has a more powerful antiproliferative effect than rutin (Araújo et al., 2013). This information adds importance to the high contents of isoquercetin found in berries of 'Chenin Blanc' grapevines on rootstock 'IAC 572' and trellised in lyre, during production cycle 1 , in this study.

\section{Factors that influence accumulation of stilbenes}

Stilbenes are not correlated to sensory quality or stability of wine grapes, but these phenolic compounds raise interest due to the relevant benefits to human health (Ali et al., 2010).

Stilbene biosynthesis derives from the general phenylpropanoid route, in the phenylalanine path, which involves the enzymes PAL, cinnamate-4-hydroxylase (C4H), 4-coumarate: CoA ligase (4CL) and stilbene synthase (STS). The product in this path is trans-resveratrol, which may be isomerized into cis-resveratrol or piceatannol (Jeandet et al., 2014). As PAL is the precursor enzyme of the stilbene route and, as its activity is related to the physiological state of the plant and influenced by radiation, its interference in the stilbene biosynthesis path can be attested. However, the results of this study show that the stilbene contents were balanced in both production cycles evaluated, achieving their potential maximum values for Chenin Blanc cultivar, under the specific conditions of the studied factors: seasons, rootstocks, and trellis systems. Consequently, even if these elements (or others) were stimulated, a response of increased synthesis is no longer possible.

Among stilbenes, we highlight the identification of piceatannol in 'Chenin Blanc' grapes. Piceatannol is a tetrahydroxy stilbene, and like trans-resveratrol, its most important sources in human diet are grapes and wine. Unlike resveratrol, scientific papers that show detailed information on the concentration of piceatannol in grapes are scarce (Antoniolli et al., 2015). Different studies have shown that piceatannol contents in grapes are four-fold lower than those of resveratrol (Piotrowska et al., 2012). This differs from our findings with 'Chenin Blanc' grapes and may represent an important differential considering the antioxidant potential of this compound. 
We highlight the greater contribution of grape skin to the content of phenolic compounds in the skin + pulp fraction of the berry (Rebello et al., 2013). The largest concentration in the skin compared to the pulp is characteristic for all grape cultivars and adds value to the products elaborated with the inclusion of grape skin.

Finally, the correlation between the regional climatic condition, the trellis system, and the rootstock, according to the harvest date, may increase accumulation of these compounds and functional properties of grapes (Brillante et al., 2015). This response may affect the quality of wines and other products and subsidize the proposal of strategies to increase the market share of tropical wines of Chenin Blanc cultivar.

\section{Conclusion}

Trellis system, a specific rootstock, and the predominant environmental conditions of production cycles in which the harvests of the first and second halves of the year occur are factors that influence the accumulation of most phenolic compounds of 'Chenin Blanc' wine grapes in tropical crops. The production cycle characterized by high solar radiation and high temperatures promotes increased accumulation of phenolic compounds. The use of adequate trellis systems and rootstocks, which provide the appropriate exposure of berries to those environmental factors, maximizes the content of some important bioactive compounds. Our data corroborated the assumption that selection of the best combination between the trellis system and rootstock must take into consideration climatic conditions of each production cycle in the cultivation region, as well as which phenolic compounds may have their accumulation stimulated. This allows grape quality differentiation and adds value to grape products in regions with tropical semi-arid climate.

\section{Authors' Contributions}

Conceptualization: Lima, M.A.C. Data acquisition: Costa, R.R.; Costa, J.P.D.; Rodrigues, A.A.M.; Vasconcelos, V.A.F.; Lima, M.A.C. Data analysis: Lima, M.A.C.; Vasconcelos, V.A.F.; Costa, R.R. Design of methodology: Lima, M.A.C.; Costa, J.P.D.; Costa, R.R. Writing and editing: Costa, R.R.; Lima, M.A.C.

\section{References}

Ali, K.; Maltese, F.; Choi, Y.; Verpote, R. 2010. Metabolic constituents of grapevine and grape: derived products. Phytochemistry Reviews 9: 357-378.

Alvares, C.A.; Stape, J.L.; Sentelhas, P.C.; Gonçalves, J.L. de M.; Sparovek, G. 2013. Köppen's climate classification map for Brazil. Meteorologische Zeitschrift 22: 711-728.

Antoniolli, A.; Fontana, A.R.; Piccoli, P.; Bottini, R. 2015. Characterization of polyphenols and evaluation of antioxidant capacity in grape pomace of the cv. Malbec. Food Chemistry 178: $172-178$.
Araújo, M.E.M.B.; Franco, Y.E.M.; Alberto, T.G.; Sobreiro, M.A.; Conrado, M.A.; Priolli, D.G.; Sawaya, F.; Ruiz, A.L.T.G.; Carvalho, J.E.; Carvalho, P.O. 2013. Enzymatic de-glycosylation of rutin improves its antioxidant and antiproliferative activities. Food Chemistry 141: 266-273.

Badhani, B.; Sharma, N.; Kakkar, R. 2015. Gallic acid: a versatile antioxidant with promising therapeutic and industrial applications. RSC Advances 35: 27540-27557.

Brillante, L.; Tomasi, D.; Gaiotti, F.; Giacosa, S.; Torchio, F.; Segade, S.R.; Siret, R.; Zouid, I.; Rolle, L. 2015. Relationships between skin flavonoid content and berry physical-mechanical properties in four red wine grape cultivars (Vitis vinifera L.). Scientia Horticulturae 197: 272-279.

Camm, E.L.; Towers, G.H.N. 1973. Phenyalanine ammonia lyase. Phytochemistry 12: 961-973.

Cruz-Zúñiga, J.M.; Soto-Valdez, H.; Peralta, E.; Mendoza-Wilson, A.M.; Robles-Burgueño, M.R.; Auras, R.; Gámez-Meza, N. 2016. Development of an antioxidant biomaterial by promoting the deglycosylation of rutin to isoquercetin and quercetin. Food Chemistry 204: 420-426.

Dias, F.A.N.; Mota, R.V.; Fávero, A.C.; Purgatto, E.; Shiga, T.M.; Souza, C.R.; Pimentel, R.M.A.; Regina, M.A. 2012. 'Syrah' vine on different rootstocks in winter cycle in the south of Minas Gerais State, Brazil = Videira 'Syrah' sobre diferentes portaenxertos em ciclo de inverno no sul de Minas Gerais. Pesquisa Agropecuária Brasileira 47: 208-215 (in Portuguese, with abstract in English).

Downey, M.O.; Harvey, J.S.; Robinson, S.P. 2004. The effect of bunch shading on berry development and flavonoid accumulation in Shiraz grapes. Australian Journal of Grape and Wine Research 10: 55-73.

Fagherazzi, G.; Vilier, A.; Lajous, M.; Boutron-Ruault, M.C.; Balkau, B.; Clavel-Chapelon, F.; Bonnet, F. 2014. Wine consumption throughout life is inversely associated with type 2 diabetes risk, but only in overweight individuals: results from a large female French cohort study. European Journal of Epidemiology 29: 831839.

Ferrer, M.; Echeverría, G.; Gonzalez-Neves, G. 2015. Influence of the microclimate defined by the training system on the vineyard behaviour and the oenological quality of Merlot grapes. International Journal of Agricultural Sciences and Natural Resources 2: 95-108.

García-Estévez, I.; Quijada-Morín, N.; Rivas-Gonzalo, J.C.; Martínez-Fernández, J.; Sánchez, N.; Herrero-Jiménez, C.M.; Escribano-Bailón, M.T. 2017. Relationship between hyperspectral indices, agronomic parameters and phenolic composition of Vitis vinifera cv. Tempranillo grapes. Journal of the Science of Food and Agriculture 97: 4066-4074.

Giuffrè, A.M. 2013. HPLC-DAD detection of changes in phenol content of red berry skins during grape ripening. European Food Research and Technology 237: 555-564.

Hickey, C.C.; Kwasniewski, M.T.; Wolf, T.K. 2018. Leaf removal effects on Cabernet Franc and Petit Verdot. II. Grape carotenoids, phenolics, and wine sensory analysis. American Journal of Enology and Viticulture. DOI: 10.5344/ajev.2018.17107

Jeandet, P.; Clément, C.; Courot, E. 2014. Resveratrol production at large scale using plant cell suspensions. Engineering in Life Sciences 14: 622-632. 
Katerji, N.; Daudet, F.A.; Carbonneau, A.; Ollat, N. 1994. Photosynthesis and transpiration studies with traditionally and Iyre-trained vine. Vitis 33: 197-203 (in French, with abstract in English).

Khaliq, G.; Tengku, M.; Mohamed, M.; Ghazali, H.M.; Ding, P.; Ali, A. 2016. Influence of gum arabic coating enriched with calcium chloride on physiological, biochemical and quality responses of mango (Mangifera indica L.) fruit stored under low temperature stress. Postharvest Biology and Technology 111: 362-369.

Larrauri, J.A.; Rupérez, P.; Saura-Calixto, F. 1997. Effect of drying temperature on the stabilitity of polyphenols and antioxidant activity of red grape pomace peels. Journal of Agricultural and Food Chemistry 45: 1390-1393.

Leão, P.C.S.; Nunes, B.T.G.; Lima, M.A.C. 2016. Canopy management effects on 'Syrah' grapevines under tropical semiarid conditions. Scientia Agricola 73: 209-216.

Lira, M.M.C.; Oliveira, L.D.S.; Vale, C.N.C.; Leão, P.C.S.; Moura, M.S.B. 2017. Influence of trellis system on microclimate of 'Chenin Blanc' grapevine = Influência dos sistemas de condução no microclima da videira 'Chenin Blanc'. Agrometeoros 25: 121-131 (in Portuguese).

Lima, M.S.; Silani, I.S.V.; Toaldo, I.M.; Corrêa, L.C.; Biasoto, A.C.T.; Pereira, G.E.; Bordignon-Luiz, M.; Ninow, J.L. 2014. Phenolic compounds, organic acids and antioxidant activity of grape juices produced from new Brazilian varieties planted in the northeast region of Brazil. Food Chemistry 161: 94-103.

Miele, A.; Rizzon, L.A. 2017. Rootstock-scion interaction. 2. Effect on the composition of Cabernet Sauvignon grape must. Revista Brasileira de Fruticultura 39: e-434.

Natividade, M.M.P.; Corrêa, L.C.; Souza, S.V.C.; Pereira, G.E.; Lima, L.C.O. 2013. Simultaneous analysis of 25 phenolic compounds in grape juice for HPLC: method validation and characterization of São Francisco Valley samples. Microchemical Journal 110: 665-674.

Padilha, C.V.S.; Biasoto, A.C.T.; Correa, L.C.; Lima, M.S.; Pereira, G.E. 2016. Phenolic compounds profile and antioxidant activity of commercial tropical red wines (Vitis vinifera L.) from São Francisco Valley, Brazil. Journal of Food Biochemistry 41: 1-9.
Padilha, C.V.S.; Miskinis, G.A.; Souza, M.E.A.O.; Pereira, G.E.; Oliveira, D.; Bordignon-Luiz, M.T.; Lima, M.S. 2017. Rapid determination of flavonoids and phenolic acids in grape juices and wines by RP-HPLC/DAD: method validation and characterization of commercial products of the new Brazilian varieties of grape. Food Chemistry 228: 106-115.

Piotrowska, H.; Kucinska, M.; Murias, M. 2012. Biological activity of piceatannol: leaving the shadow of resveratrol. Mutation Research. Reviews in Mutation Research 750: 60-82.

Protas, J.F.S.; Camargo, U.A. 2011. Brazilian winemaking: sectorial overview of $2010=$ Vitivinicultura brasileira: panorama setorial de 2010. Sebrae, Brasília, DF, Brazil (in Portuguese).

Rebello, L.P.G.; Lago-Vanzela, E.S.; Barcia, M.T.; Ramos, A.M.; Stringheta, P.C.; Silva, P.; Castillo-Muñoz, N.; Gómez-Alonso, S.; Hermosín-Gutiérrez, I. 2013. Phenolic composition of the berry parts of hybrid grape cultivar BRS Violeta (BRS Rubea $\times$ IAC 1398-21) using HPLC-DAD-ESI-MS/MS. Food Research International 54: 354-366.

Teixeira, A.; Eiras-Dias, J.; Castellarin, S.D.; Gerós, H. 2013. Berry phenolics of grapevine under challenging environments. International Journal of Molecular Sciences 14: 18711-18739.

Vogt, T.; Pollak, P.; Taryln, N.; Taylor, L.P. 1994. Pollination- or wound-induced kaempferol accumulation in petunia stigmas enhances seed production. Plant Cell 6: 11-23.

Wang, G.; Lei, Z.; Zhong, Q.; Wu, W.; Zhang, H.; Min, T.; Wu, H.; Lai, F. 2017. Enrichment of caffeic acid in peanut sprouts and evaluation of its in vitro effectiveness against oxidative stressinduced erythrocyte hemolysis. Food Chemistry 217: 332-341.

Wang, J.; Ma, L.; Xi, H.; Wang, L.; Li, S. 2015. Resveratrol synthesis under natural conditions and after UV-C irradiation in berry skin is associated with berry development stages in 'Beihong' (V. vinifera $\times V$. amurensis). Food Chemistry 168: 430-438. 